\title{
Effect of Irrigation on Within-Grove Distribution of Red Palm Weevil Rhynchophorous ferrugineus
}

\author{
Y. Aldryhim* and S. Al-Bukiri \\ Department of Plant Protection, King Saud University \\ P.O. Box 2460, Riyadh 11451, Kingdom of Saudi Arabia \\ تأثير طريقة الري على سلوك إنتشار الإصابة بسوسة النخيل الحمراء \\ يوسف الدريهم و صالح البكري

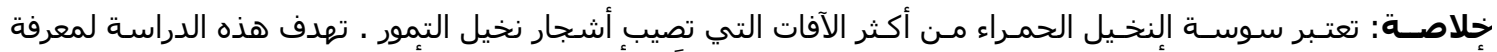

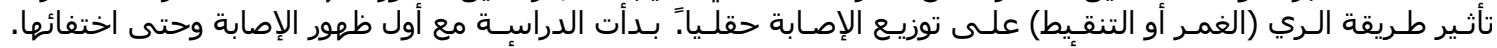

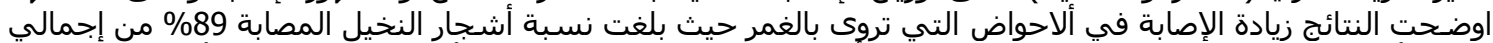

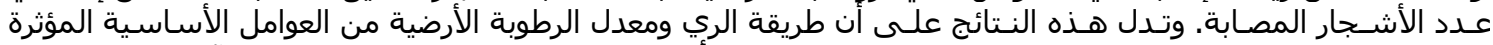

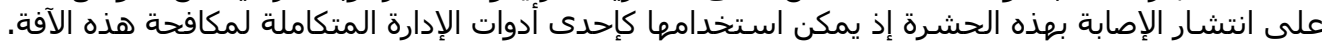

\begin{abstract}
The red palm weevil (RPW) Rhynchophorous ferrugineus (Oliv.) is the most important pest attacking date palm trees. The objective of this study was to determine the effect of drip and flood irrigation on the within-grove distribution of RPW. The current study was started with the first appearance of the infestation to almost disappearance of the infestation. Results showed that more infested trees were detected in plots with flood irrigation. The number of infested trees in these plots represented $89 \%$ of the total infested trees. This study suggested that irrigation management and soil moisture are key factors in the dispersion of the RPW infestation and could be used as one of the integrated pest management tools.
\end{abstract}

Keywords: Red palm weevil, integrated pest management, irrigation, soil moisture, infestation control.

$\mathbf{T}$ The red palm weevil (RPW) Rhynchophorous ferrugineus (Oliv.) is the most important pest of the date palm in the Middle-East (Abraham et al., 1998). The insect was discovered in Saudi Arabia in the mid-1980s (Gush, 1997; Abraham et al., 1998; Faleiro et al., 1999). Since then it has spread over most of the date palm areas (Bokhari and Abuzuhira 1992; Vidyasagar et al., 2000), due to the transfer of infested offshoots and palm trees.

RPW infestation is lethal to date trees. This is due to a lack of early and apparent external signs of the infestation. Infestation occurrs mostly in young trees of age 5-15 years (Sathiamma et al. 1992; Aldryhim, unpub. observation). Several control methods have been applied within an IPM (i.e. integrated pest management) strategy. The main components of IPM are phyto-sanitation, which involves cutting down and burning the infested trees, use of insecticides, and use of pheromone traps for monitoring and mass trapping of adult RPWs.
Phyto-sanitation is crucial in preventing or reducing subsequent infestations (Murphy and Briscoe, 1999).

There have been no reports on the within-grove distribution of RPW infestations under different watering regimes. The objective of the present work was focused on the effect of the types of irrigation on the distribution of RPW infestation in date palms within a grove.

\section{Materials and Methods}

This study was conducted in a 16,000 date palm farm in Al-Karaj oasis, $80 \mathrm{~km}$ south of Riyadh. It was started with the first appearance of infestation in May 1998 and ran to October 1999 when the level of RPW infestation became low and almost disappeared. The major cultivars were: Nepoot Seif, Khalass, Sagai and Berhi. The age of the trees varied from 5 to 25 years. Leaf pruning (Takreeb) was carried out in late autumn. 


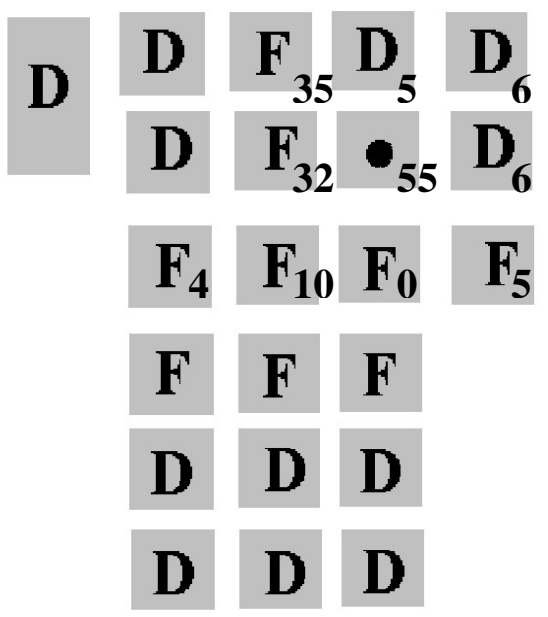

Figure 1. Outline of field showing plots and type of irrigation. $\mathrm{D}=$ dripping irrigation, $\mathrm{F}=$ flooding irrigation. Numbers refer to infested trees in plot.

The farm was divided into 22 plots, each contained $650 \pm$ 50 trees, each plot was $6500 \pm 500 \mathrm{~m}^{2}$. The distance between trees in the same row and the distance between rows was $10 \mathrm{~m}$. Flood (F) and drip (D) irrigation were used (Fig. 1). The rate of drip irrigation was $0.5-1 \mathrm{~m}^{3}$ per tree per week and per two weeks in the summer and in the winter, respectively. The rate of flood irrigation was 4-8 $\mathrm{m}^{3}$ per tree per week and per two weeks in the summer and in the winter, respectively.

Since there is no early and clear sign for infested trees, detection of the infested trees was totally depended on the scout's efforts. Once an infested tree was observed, it was cut-down and dissected to small pieces that were packed into sacks and were burned in a special incinerator. Data were taken for each infested tree such as the date on which infestation was observed, plot number and type of irrigation.

\section{Results}

Infested trees were first detected in a plot with flood irrigation. RPW spread from the hot spot, where the infestation was first appeared in May 1988, to the neighboring plots with clear preference to plots with flood irrigation (Fig. 1). Infestations were detected in six plots with flood irrigation and three plots with drip irrigation. Number of infested trees were 55, 32, 35, 5, 10, and 4 in six plots of flood irrigation and 5, 6 and 6 in three plots of drip irrigation. The number of infested trees that were detected in flood irrigation plots was 141, representing $89 \%$ of total infested trees. Whereas, 17 infested trees were detected in drip irrigation plots that representing $10 \%$ of total infested trees (Fig. 2).

\section{Discussion}

Flood irrigation created a more suitable microhabitat for RPW. It increased soil moisture contents which appears to be preferable to RPW and allows grasses to grow

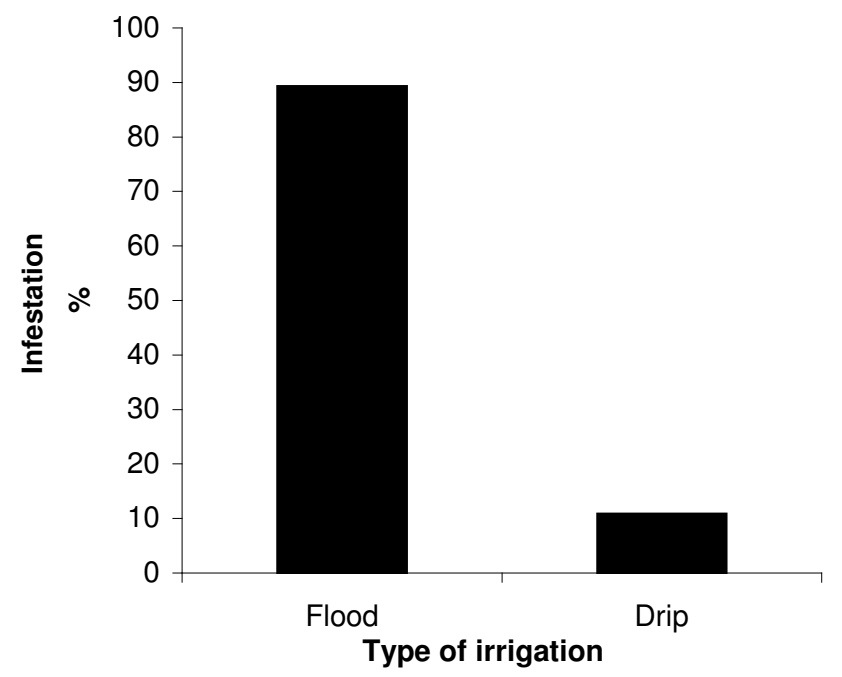

Figure 2. Distribution of infested trees in plots with flood and drip irrigation.

to a high density. The groves provide shade and reduce the evaporation rate of water from the soil. Leefmans (1920) reported that adults of RPW seek moist harborages till they find a new host. Aldryhim and Kalial (unpublished data) found that RPW adults survived up to three and 39 days in dry and moist peat moss, respectively, in the absence of the food. Also, they found that RPW adults could penetrate $20 \mathrm{~cm}$ deep in the moist peat moss; where no attempt for penetration occurred when adults were placed on dry peat moss. Giblin-Davis and Howard (1989) found that adults of a closely related species, $R$. cruentatus, suffered from high mortality when placed in petri-dishes that lacked moisture. This weevil has high cuticular permeability and is susceptible to significant water loss in dry environments (Weissling and Giblin-Davis, 1993). It chooses high relative humidity over low relative humidity in choice tests (Weissling and Giblin-Davis, 1993) and plant tissues with minimal moisture content are significantly less attractive (GiblinDavis et al., 1994).

\section{Conclusion}

The response of RPW adults to moisture is probably an important part of the insect behavioral selection but this deserves further study. It will be useful to do more research on the use of irrigation types and soil moisture as important tools in the IPM of RPW. The results obtained may help in detection of infested trees by concentrating inspection on farms that used flood irrigation.

\section{References}

Abraham, V.A. and G.B. Pillai. 1998. Red palm weevil - a dreaded enemy of coconut palm. Indian Farmers`Digest 7(1):15-20.

Abraham, V.A., M.A. Al-Shuaibi, J.R. Faleiro, R.A. Abozuhairah, and P.S.P.V. Vidyasagar. 1998. An integrated management approach for red palm weevil Rhynchophorous ferruginseus Oliv. a key pest of date palm in the Middle East. Journal of Agricultural Sciences 3:77-83. 


\section{EFFECT OF IRRIGATION ON WITHIN-GROVE DISTRIBUTION OF RED PALM WEEVIL RHYNCHOPHOROUS FERRUGINEUS}

Bokhari, V.U.G. and R.A. Abuzuhira. 1992. Diagnostic tests for red palm weevil. Rhynchophorous ferruginseus infested date palm trees. Arab Gulf Scientific Research 10:93-104.

Faleiro, J.R., M.A. Al-Shuaibi, V.A. Abraham, and T. Prem Kumar. 1999. A technique to assess the longevity of the Pheromone (Ferrolure) used in trapping the date palm weevil Rhynchophorous ferrugineus Oliv. Agricultural Sciences 4(1):5-9.

Giblin-Davis, R.M. and E.W. Howard. 1989. Vulnerability of stressed plants to attack by Rhynchophorus cruentatus (Coleoptera: Curculiondae) and insecticides control of the pest. Journal of Economic Entomology 82:1185-1190.

Giblin-Davis, R.M., T.J. Weissling, A.C. Oehlschlager, and L.M. Gonzalez. 1994. Field response of Rhynchopharus cruentatus (Coleoptera: Curculionidae) to its aggregation pheromone and fermenting plant volatiles. Florida Entomology 77:164-177.

Gush, H. 1997. Date with disaster. The Gulf Today, Sept. 29, p. 16.

Leefmans, S. 1920. De Palmsnuitkever (Rhynchophorus ferrugineus Oliv.). Meded. Inst. Plziekr. 43:1-90.
Murphy, S.T. and B.R. Briscoe. 1999. The red palm weevil as an alien invasive: biology and the prospects for biological control as a component of IPM. Biocontrol News and Information 20(1):35-46.

Sathiamma, B., V.A. Abraham, and C. Kurian. 1992. Integrated pest management of the major pests of coconut. Indian Coconut Journal January:27-29.

Vidyasagar, P.S.P.V., M. Hagi, R.A. Abozuhairah, O.E. Al-Mohanna, and A. Al-Saihati. 2000. Impact of mass pheromone trapping on the red palm weevil: Adult population and infested level in date palm Gardens of Saudi Arabia. The Planter 76:347-355.

Weissling, T. and R.M. Giblin-Davis. 1993. Water loss dynamic and humidity preference of Rhynchoporus cruentatus (Coleoptera: Curculiondae) adults. Environmental Entomology 22:93-98.

Received March 2002.

Accepted September 2002. 